\title{
A Balaton déli partjáról elökerült honfoglalás kori magányos lovas temetkezések embertani elemzése
}

\author{
'BUZÁR ÁGOTA - ²BERNERT ZSOLT \\ 1,2 Magyar Természettudományi Múzeum, Embertani Tár, H-1083, Budapest, Ludovika tér 2-6. \\ e-mail: buzar.agota@nhmus.hu, bernert.zsolt@nhmus.hu
}

BUZÁR, Á. - BERNERT, Zs.: Anthropological analysis of a single Conquering-period horse burials from the southern bank of Lake Balaton Abstract: Those Conquering-period horse burials found in Landler Jenő street in Balatonszemes, 4 Arany János Street in Balatonlelle, and Magyar Bálint Elementary School in Fonyód are similar to those solitary and symbolic horse burials found in other areas of the Carpathian Basin, which cannot be tied to settlement areas.

Keywords: Hungarian Conquest Period, symbolic horse burial, physical anthropology

\section{Bevezetés}

A Balaton mocsaras, vizekben gazdag déli előtere a nagyállattartó életmódot folytató népek számára minden korban jó életteret biztosított, számos avar és honfoglalás kori lelőhely tanúsítja ezt. A szálláshelyhez köthető nagy sírszámú temetők a korabeli lakosság nagyobb létszámára utalnak, ezek közül kiemelkednek Zamárdi-Réti földek és Vörs temetkezései. A klasszikus honfoglalás kori (a középréteg sírjait rejtő) temetkezések Somogy megyében föleg a Balaton partján, illetve attól nem messze kerültek elő (Vörs, Fonyód, Balatonlelle, Balatonszemes, Balatonújlak). Ezek részben még a „kalandozásokban” résztvevő harcosok nyughelyei lehettek, amit a sírjaikban talált nyugati pénzek (Berengár itáliai király, majd császár, Lothar és Provence-i Hugo ezüst denárjai) jeleznek. ${ }^{1}$ A lakosság temetőitől eltérnek a magányos, lovas sírok, amelyek történeti-régészeti megítélése nem egyértelmű. Korábban elterjedt volt a kutatók között az a nézet, hogy más sztyeppei népek (hunok, avarok, stb) példájára a magyarok is titokban, rejtve, magányosan helyezték örök nyugalomra fejedelmeiket. ${ }^{2}$

\section{Balatonszemes, Landler Jenő utca}

1988. májusában leletmentő ásatás során Balatonszemesen, a Landler Jenő utcában, magányos lovas sír került feltárásra Költő László régész vezetésével. A helyben maradt vázrészek alapján a sír tájolása ÉNy-DK lehetett. A hiányos emberi csontváz (1. sír) mellékleteként kengyel, csüngős szügyelőveret, aranyozott ezüst csatok, övveretek, kisszíjvégek, vasalt tegez, Berengár rex (885-915) és Berengár imperator (914-924) milánói veretei, valamint Teophilius, II. Mihály és Constantin császárok együttes uralkodása idején vert, arany solidus negyedelt darabja került elő. Megfigyelhető volt a vasalt tegez hossza, és előkerült egy villás és egy négyélü nyílcsúcs is. ${ }^{3}$ A sírban agyag- és vastöredékeken kívül lócsontokat és egyéb állatcsontokat is találtak. A feltárt lócsontok és mellékletek alapján a sírt honfoglalás kori részleges lovas temetkezésként azonosították. A honfoglaló sírra merőlegesen, attól 3 méterre egy melléklet nélküli sírt is feltártak (2. sír), amelynek a régész véleménye szerint nincs köze a honfoglaló sírhoz. Az emberi maradványokat 1989-ban Pap lldikó kapta meg embertani vizsgálatra. 2016-ban újabb, a vázhoz tartozó csontok kerültek a Természettudományi Múzeum Embertani Tárába, ez indokolta a maradványok újbóli értékelését.

\section{Balatonlelle, Arany János utca 4.}

Balatonlellén 1991-ben az Arany János utca 4. szám alatt árokásás során került elő egy honfoglalás kori sír. ${ }^{4}$ A K-Ny-i tájolású, nyújtott helyzetű, háton fekvő emberi csontváz bal lábánál ló koponyája és lábcsontjai kerültek el. A többszörösen bolygatott sírból csupán négy nyílhegy, egy zabla és egy kengyelpár maradt meg. Mellékletei alapján Mesterházy Károly a honfoglalók első generációjának egyik tagját látta benne. ${ }^{5}$ Varga Máté szerint a halottat a 10. század elejétől a 11. század első kétharmadáig bármikor eltemethették, de a legnagyobb valószínűséggel a 10. század második felére keltezhető a temetkezés. ${ }^{6}$

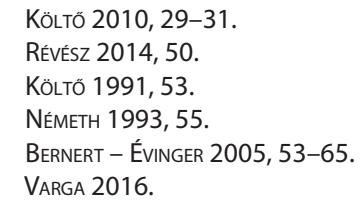




\section{Fonyód, Magyar Bálint Általános Iskola}

1988-ban az iskola tornaterme mellett ásott vízelvezető árokban, mintegy 2 méter mélyen, csontvázra bukkantak a munkások. A leletmentés során Költő László régész vezetésével feltárásra került egy bolygatatlan honfoglalás kori lovas sír. A mellékletei alapján a 10. század második harmadára keltezik. Az elhunytat aranyozott veretes övvel, veretes zárószíjú tarsollyal, arany lemezből kinyírt csüngőkkel és legalább hét nyílcsúccsal temették el. Felső ruhájára csuklónál és bokánál ezüst lemezeket erősítettek, övére két itáliai érme (Lothar és Provence-i Hugo együttes veretei, 922-946) volt felvarrva. Előkerült továbbá a láb fölé temetett összegöngyölt lóbőr, csikózabla, egy pár körte alakú kengyel és a lószerszámon ezüst lemezből kivágott csíkok is. ${ }^{7}$

\section{Anyag és módszer}

A Balatonszemes, Landler Jenő utca emberi maradványait 2016.10.1. és 2016.10.2. leltári számmal vettük nyilvántartásba. A Balatonlelle, Arany János utca 4. szám alatti egyén 2004.6.1. leltári számmal került nyilvántartásba vételre. A Fonyód, Magyar Bálint Általános Iskola lelőhelyen feltárt egyén 2005.11.1. számmal lett beleltárazva.

A morfológiai nem meghatározásánál a nemi dimorfizmust mutató anatómiai jellegeket, ${ }^{8}$ és a csontok abszolút méreteit vettük figyelembe. ${ }^{9}$ A testmagasság számításánál Sjøvold módszerét használtuk. ${ }^{10}$

A biológiai életkor becslésénél a szimfízis felszínének változása, ${ }^{11}$ a bordavégek alapján, ${ }^{12}$ valamint a koponyavarratok elcsontosodásának figyelembevételével ${ }^{13}$ becsültük a biológiai életkort. A csontokat Martin útmutatása alapján mértük. ${ }^{14}$

\section{Eredmények}

\section{Balatonszemes, Landler Jenö utca}

1. sír, leltári száma: 2016.10.1.

A csontváz töredékes állapotú, erősen hiányos, a koponyája és az állkapcsa hiányzik. A vázrészeken sok postmortem törést találtunk. Több postcranialis csonton zöldes elszíneződés, patina nyomai figyelhetők meg (bordák, keresztcsont, medencelapát, felkarcsont, ujjpercek). A szimfízis és a bordavég alapján határozott biológiai életkora 25-29 év.

A nemi jellegek közül a combcsont fejét (caputfemoris), a keresztcsontot (os sacrum), valamint a csípőcsontot (os ilium) tudtuk vizsgálni. Az előbbi nemi jellegek, valamint a vázcsontok nagy abszolút mérete alapján a morfológiai neme férfi. A combcsont alapján számított testmagassága 173 centiméter volt.

A vázon megfigyeltünkegy gyógyult törést. A jobb orsócsont (radius) distalis végén kismértékű diszlokációval gyógyult törés figyelhető meg, ez tipikusan esés következtében elszenvedett fraktúra.

A keresztcsonton egy fejlődési rendellenességet jegyeztünk fel, az utolsó ágyékcsigolya hozzácsontosodott a keresztcsonthoz (sacralisatio).

\begin{tabular}{|l|c|c|}
\hline & bal (mm) & jobb (mm) \\
\hline combcsont (femur) & - & 469 \\
\hline sípcsont (tibia) & 390 & 388 \\
\hline szárkapocscsont (fibula) & 389 & 392 \\
\hline sarokcsont (calcaneus) & - & 85 \\
\hline
\end{tabular}

1. táblázat. Vázcsontok metrikus adatai, Balatonszemes

2. sír, leltári száma: 2016.10.2.

A 2. sír a régész véleménye szerint nem köthető az 1. sírhoz, attól merőlegesen, 3 méternyi távolságban tárták fel. A sír melléklet nélküli. A koponya töredékes, hiányos, állkapcsa nincs, a postcranialis váz is erősen töredékes, hiányos. A combcsont hossza alapján (243 mm) a váz egy 7-8 éves (Infans II.) gyermeké.

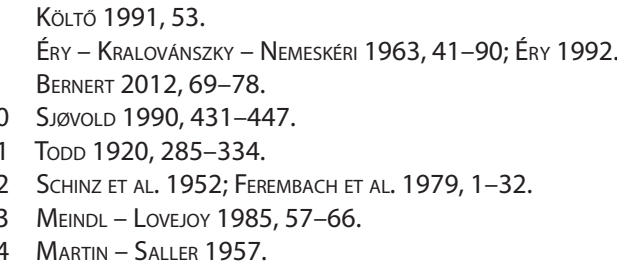




\section{A BALATON DÉLI PARTJÁRÓL ELŐKERÜLT HONFOGLALÁS KORI MAGÁNYOS LOVAS TEMETKEZÉSEK EMBERTANI ELEMZÉSE}

\section{Balatonlelle, Arany János utca 4.}

1. sír, leltári száma: 2004.6.1.

A koponya és a vázcsont töredékes és hiányos, az állkapocs ép, erőteljes. A 25-35 év körüli férfi koponyacsontjai szokatlanul vékonyak voltak, ami ellentétben áll erőteljes állkapcsával. A közepes termetű gracilis csontozatú férfi testmagassága 166 centiméter volt. A lapát alakú felső metszőfogak mongoloid származását valószínűsítik. ${ }^{15} \mathrm{~A}$ maradvány részletes patológiai elemzésénél a gerinc háti és ágyéki szakaszának fokozottabb igénybevételére utaló Schmorl-herniát írtunk le, az 5. ágyékcsigolyán pedig csigolyaív-szakadás (spondylolysis) figyelhető meg.

\begin{tabular}{|l|c|c|}
\hline & bal (mm) & jobb (mm) \\
\hline kulcscsont (clavicula) & - & 148 \\
\hline felkarcsont (humerus) & 321 & - \\
\hline orsócsont (radius) & 248 & 441 \\
\hline combcsont (femur) & 444 & - \\
\hline sarokcsont (calcaneus) & 84 & - \\
\hline ugrócsont (talus) & 55 & - \\
\hline
\end{tabular}

2. táblázat. Vázcsontok metrikus adatai, Balatonlelle

\begin{tabular}{|c|c|}
\hline Martin-féle mérőszámok & Méret $(\mathbf{m m})$ \\
\hline 65 & 125 \\
\hline 66 & 101 \\
\hline 69 & 26 \\
\hline 70 & 62 \\
\hline 71 & 33 \\
\hline
\end{tabular}

3. táblázat. Állkapocs metrikus adatai, Balatonlelle

\section{Fonyód, Magyar Bálint Általános Iskola}

1. sír, leltári száma: 2005.11.1.

A 15-17 éves egyén koponyája és állkapcsa töredékes és hiányos. A váz ép és teljes. ${ }^{16}$ Az alkarcsontokon, lábszárcsontokon, bordákon és a csípőlapáton zöld patinanyom figyelhető meg. A részletes morfológiai vizsgálat alapján, bár a koponyán számos nőies nemi jelleg található, a vázcsontok (medence, hosszúcsontok) alapján az elhunyt férfi lehetett. A koponya nem alkalmas taxonómiai elemzésre, az állkapocs testének íveltsége („hintázó állkapocs”) azonban keleti eredetre utal. A combcsontja alapján számított testmagassága legalább 168 centiméter volt, ha megérte volna a felnőttkort, jóval magasabb is lehetett volna. A patológiai vizsgálat során több elváltozást írtunk le: az arcüregében gyulladás (sinusitis) nyomait, a jobb felkarcsontjának distalis epiphysis-ében erőteljes porc-és csontdegenerációval járó körülhatárolt csontléziót figyeltünk meg. A végtagcsontokon több helyen (alkarcsontok, combcsont, lábszárcsontok, stb.) csonthártyagyulladás (periostitis) nyomai látszódtak, amely a halála környékén lezajlott heveny gyulladásra utalnak.

\begin{tabular}{|c|c|c|}
\hline & bal $(\mathrm{mm})$ & jobb $(\mathrm{mm})$ \\
\hline Sarokcsont (calcaneus) & 78 & 78 \\
\hline Ugrócsont (talus) & 54 & 54 \\
\hline
\end{tabular}

4. táblázat. Vázcsontok metrikus adatai, Fonyód

15 BERNERT - ÉVINGER 2005, 53-65.

16 BERNERT - ÉVINGER - HAJDU 2006, 53-68. 


\begin{tabular}{|l|l|l|l|l|l|}
\hline & Leltári szám & \multicolumn{1}{|c|}{$\begin{array}{c}\text { Morfológiai } \\
\text { nem }\end{array}$} & Elhalálozási kor & $\begin{array}{c}\text { Mongoloid } \\
\text { jelleg }\end{array}$ & $\begin{array}{c}\text { Testmagasság } \\
\text { (cm) }\end{array}$ \\
\hline $\begin{array}{l}\text { Balatonszemes, } \\
\text { Landler Jenő utca }\end{array}$ & 2016.10 .1$. & férfi & $25-29$ év & $\begin{array}{l}\text { nem } \\
\text { vizsgálható }\end{array}$ & $173 \mathrm{~cm}$ \\
\hline $\begin{array}{l}\text { Balatonlelle, Arany } \\
\text { János utca }\end{array}$ & 2004.6 .1$. & férfi & $25-35$ év & + & $166 \mathrm{~cm}$ \\
\hline $\begin{array}{l}\text { Fonyód, Magyar } \\
\text { Bálint Általános } \\
\text { Iskola }\end{array}$ & 2005.11 .1 & férfi & $15-17$ év & + & $168 \mathrm{~cm}$ \\
\hline
\end{tabular}

5. táblázat. A három lelöhely embertani adatainak összevetése

\title{
Összefoglalás
}

A Balatonszemes, Landler Jenő utcában, Balatonlelle, Arany János utca 4. szám alatt, illetve Fonyód, Magyar Bálint Általános Iskolában talált honfoglaló lovas sírok jól illeszkednek a Kárpát-medence más részein feltárt magányos, részleges lovas temetkezések sorába, amelyek feltehetően nem köthetők szállásterülethez. Közös jellemzőjük, hogy az elhunytak fiatal férfiak voltak, gazdag mellékletekkel eltemetve, sírjaikból lócsontok és lószerszám is előkerült. Az éremleletek és egyéb mellékleteik alapján a temetkezések a 10. század második felére, második harmadára tehetők. A balatonlellei és a fonyódi elhunyt koponyája töredékes állapotban volt, a balatonszemesi koponya hiányzott. Klasszikus taxonómiai vizsgálatra töredékességük miatt nem voltak alkalmasak, azonban mindkét töredékes koponyánál meg tudtunk figyelni olyan morfológiai jelleget, amely europid népességeknél ritka, a közép- és kelet-ázsiai népességeknél fordul elő gyakrabban. A balatonszemesi férfi a magas, a balatonlellei és fonyódi halottak a nagyközepes termetkategóriába tartoztak.

\section{Anthropological analysis of a single Conquering-period horse burials from the southern bank of Lake Balaton}

\author{
ÁGOTA BUZÁR - ZSOLT BERNERT
}

Those Conquering-period horse burials found in Landler Jenő street in Balatonszemes, 4 Arany János Street in Balatonlelle, and Magyar Bálint Elementary School in Fonyód are similar to those solitary and symbolic horse burials found in other areas of the Carpathian Basin, which cannot be tied to settlement areas. Common features are that the deceased were young men buried with rich artifacts, and found with horse bones and equestrian tools. Based on medals and other artifacts, the burials can be dated to the second-half of the $10^{\text {th }}$ century. The skulls from Balatonlelle and Fonyód were fragmentary, and the skulls was missing from the burial at Balatonszemes. Classical taxonomic analysis could not be completed due to the fragmentary nature of the skulls, but morphological characteristics were found that are rarely seen in European samples, and more frequently seen in middle and eastern Asian samples. The man from Balatonszemes can be classed as tall, while the individuals from Balatonlelle and Fonyód are of medium-large stature. 


\section{A BALATON DÉLI PARTJÁRÓL ELŐKERÜLT HONFOGLALÁS KORI MAGÁNYOS LOVAS TEMETKEZÉSEK EMBERTANI ELEMZÉSE}

\section{Irodalom}

BERNERT - ÉVINGER 2005 Bernert Zsolt - Évinger Sándor: Adatok Somogy megye embertanához. Folia Anthropologica 3. 53-65.

BERNERT - ÉVINGER - HAJDU 2006 Bernert Zsolt - Évinger Sándor - Hajdu Tamás: További adatok Somogy megye embertanához. Folia Anthropologica 4. 53-68.

BERNERT 2012 Bernert Zsolt: Adatok a morfológiai nem meghatározásához és a nemi arány értékeléséhez Kárpát-medencei történeti szériák alapján. Anthropológiai Közlemények 53. 69-78.

ÉRY 1992 Éry Kinga: Útmutató a csontvázleletek feldolgozásához (Posztgraduális szakképzés jegyzete). ELTE Embertani Tanszék, Kézirat, Budapest, 1992.

ÉRY - KrALOVÁNSZKY - NemESKÉRI 1963 Éry Kinga - Kralovánszky Alán - Nemeskéri János: Történeti népességek rekonstrukciójának reprezentációja. Anthropológiai Közlemények 7.41-90.

Ferembach - Schwidetzky - Stloukal 1979 Ferembach, Denise - Schwidetzky, Ilse - Stloukal, Milan: Empfehlungen für die Alters- und Geschlechtsdiagnose am Skelett. Homo 30. 1-32.

KöLtő 1991 Költő László: Fonyód-Magyar Bálint Általános Iskola Régészeti Füzetek Ser. 1/42. 53.

KöLtő 2010 Költő László: Avar és honfoglalás kori temetők. Somogyi Múzeumok Közleményei 19. 29-31.

MARTIN - SALleR 1957 Martin, Rudolf - Saller, Karl: Lehrbuch der Antropologie I. Stuttgart, 1957.

MEINDL - LoveJor 1985 Meindl, Richard S. - Lovejoy, C. Owen:Ectocranial Suture Closure: A Revised Method for the Determination of Skeletal Age at Death Based on the Lateral-Anterior Sutures. American Journal Physical Anthropology 68. 57-66.

NÉmETH 1993 Németh Péter Gergely: Balatonlelle, Arany J. u. 4. Régészeti Füzetek Ser. 1/45. 55.

RÉvész 2014 Révész László: A magyar honfoglalás kora. Budapest, 2014.

SృøVold 1990 Sjøvold, Torstein: Estimation of stature from long bones utilizing the line of organic correlation. Human Evolution 5. 431-447.

TodD 1920 Todd, T. Wingate: Age Changes in the Pubis Bone: I, The Male White Pubis. American Journal Physical Anthropology 3. 285-334.

UBELAKER 1989 Ubelaker, Douglas H.: Human Skeletal Remains, Excavation, Analysis, Interpretation. Washington:Taraxacum, 1989.

VARGA 2016 Varga Máté: Honfoglalás kori lovas sírja Balatonlellén. Kézirat, 2016. 
